\title{
Lectin-reactive components of the microsporidian Glugea plecoglossi and their relation to spore phagocytosis by head kidney macrophages of ayu Plecoglossus altivelis
}

\author{
Jeong-Ho Kim*, Kazuo Ogawa, Hisatsugu Wakabayashi \\ Department of Aquatic Bioscience, Graduate School of Agriculture and Agricultural Life Sciences, The University of Tokyo,
} Tokyo 113-8657, Japan

\begin{abstract}
We investigated the reactivity of lectins to spores of Glugea plecoglossi from ayu Plecoglossus altivelis. Smear preparations of purified spores were treated with 8 kinds of lectins. Lectin blots were used to detect glycoproteins of spore lysates. In addition, lectin-treated spores were applied to head kidney macrophages of ayu, and the percentage of phagocytosis (PP) was calculated and compared with the control. Two lectins (ConA, WGA) reacted with the surface of the spores, and a major band $(55 \mathrm{kDa})$ and some minor bands were visualized on blots after treatment with these. PP was decreased after ConA treatment. From these results, we suggest that $G$. plecoglossi spores can be phagocytized by ayu head kidney macrophages via ConA-reactive glycoprotein-mediated recognition.
\end{abstract}

KEY WORDS: Glugea plecoglossi Microsporidian $\cdot$ Plecoglossus altivelis $\cdot$ Lectin $\cdot$ Phagocytosis

\section{INTRODUCTION}

Obligatory intracellular parasites must enter target cells for successful infection and proliferation. This phenomenon implies that the parasites must recognize and bind to the host cell surface before entering. This recognition can be accomplished by the interaction of carbohydrate-binding proteins on the parasites and complementary sugars on the host cells, or vice versa (Sharon 1984).

Lectins are carbohydrate-binding proteins and are widely distributed in nature (Jacobson \& Doyle 1996). Since the first report of haemagglutinating proteins extracted from castor bean Ricinus communis in 1888 many lectins have been detected in plants, animals and microorganisms (Beuth et al. 1995). They play a key role in the control of various normal and patho-

\footnotetext{
- Present address: Laboratory of Aquatic Animal Diseases, College of Veterinary Medicine, Chungbuk National University, Cheongju, Chungcheongbuk-do, 360-763, Korea.

E-mail:kimjh89@yahoo.com
}

genic processes in living organisms (Sharon \& Lis 1989). There is evidence that many intracellular protozoan parasites have special mechanisms to enter host cells, and these strategies are at least partially related to lectin-reactive proteins (Scott \& Snary 1979, Schulman et al. 1984, Hernandez et al. 1986, Ezekowitz et al. 1991).

Microsporidia are obligatory intracellular protozoan parasites, and the only life cycle stages which can exist outside the host cells are the dormant spores (Vavra et al. 1998). Infection usually occurs when the spores are ingested by susceptible hosts. With appropriate stimuli, they evert the polar tube and inject the sporoplasm into the target host cells, probably epithelial cells lining the gastrointestinal tract. When ingested by macrophages or other phagocytic cells before germination, spores can be killed and digested. However, some spores may survive by escaping from lysosomal fusion, and these spores may initiate infection by germinating inside those cells, which can become the infection foci (Schmidt \& Shadduck 1984, Weidner \& Sibley 1985). Considering this, interactions of microsporidian spores 
and macrophages may be an important step in establishing infection.

We investigated the lectin-reactivity of the microsporidian parasite Glugea plecoglossi of ayu Plecoglossus altivelis using various methods. We also investigated the effect of lectin treatment on the phagocytosis of spores by head kidney macrophages of ayu.

\section{MATERIALS AND METHODS}

Parasites. Fresh spores of Glugea plecoglossi were isolated from heavily infected ayu and purified as described previously (Kim et al. 1998).

Lectin-binding pattern of Glugea plecoglossi spores. Purified mature spore suspensions of Glugea plecoglossi were smeared on slide glasses, air-dried and methanol-fixed. The lectin-based staining procedure followed the method of Hedrick et al. (1992), with some modifications. Briefly, the slides were rinsed with PBS (2.7 $\mathrm{mM} \mathrm{KCl}, 1.5 \mathrm{mM} \mathrm{KH}_{2} \mathrm{PO}_{4}, 0.14 \mathrm{M} \mathrm{NaCl}, 8.1 \mathrm{mM}$ $\mathrm{Na}_{2} \mathrm{HPO}_{4}, \mathrm{pH} 7.4$ ) for $5 \mathrm{~min}$ and incubated with $50 \mu \mathrm{l}$ of 8 different biotinylated lectins $\left(10 \mu \mathrm{g} \mathrm{ml}^{-1}\right.$ in PBS, Wako, Japan) in a moist chamber for $1 \mathrm{~h}$ at room temperature (RT). The characteristics of lectins used in this study are summarized in Table 1 . After 3 washings in PBS for 5 min each, the slides were incubated with $50 \mu \mathrm{l}$ of fluorescein avidin D $\left(5 \mu \mathrm{g} \mathrm{ml}^{-1}\right.$ in PBS, Sigma, St. Louis, Missouri, USA) and incubated in a moist chamber for 30 min at RT again. After 3 washes in PBS, the slides were carefully blotted to near dry and mounted in $90 \%$ glycerol (in PBS) with a coverslip. Smear preparations were observed using fluorescence microscopy.

SDS-PAGE and lectin blot. Parasite proteins were solubilized by boiling in buffer containing $150 \mathrm{mM}$ Tris- $\mathrm{HCl}, \mathrm{pH} 6.8,4 \%$ SDS, $10 \%$ 2-mercaptoethanol and $20 \%$ glycerol and SDS-PAGE was conducted according to the method of Laemmeli (1970). Electrophoretic transfer onto polyvinylidene difluoride (PVDF) membranes (Atto, Japan) was then carried out for $90 \mathrm{~min}$, at $144 \mathrm{~V}$ in buffer containing $192 \mathrm{mM}$ glycine, $100 \mathrm{mM}$ Tris base and $5 \%$ methanol.

Table 1. Lectins used in this study

\begin{tabular}{|lll|}
\hline Lectin origin & Acronym & Major sugar specification \\
\hline Canavalia ensiformis & ConA & $\alpha$-D-Man> $\alpha$-D-Glc $\beta$ \\
Dolichos biflorus & DBA & $(\alpha-\mathrm{D}$-GalNAc) \\
Lens culinaris & LCA & $\alpha$-D-Man $>\alpha$-D-Glc \\
Arachis hypogaea & PNA & Gal- $\beta$ - $(1-3)$-GalNAc \\
Glycine max & SBA & D-GalNAc $>$ D-Gal \\
Ulex europaeus & UEA-I & $\alpha$-L-fucose \\
Triticum vulgaris & WGA & $(\beta$-GlcNAc $)>$ NeuNac \\
Phaseolus vulgaris & PHA-E4 & $(\alpha$-GalNAc $)>(\beta-G a l N A c)$ \\
& & \\
\hline
\end{tabular}

The glycoproteins blotted on PVDF membranes were identified by the method of Thornton et al. (1994). After washing in distilled water for 5 min, strips were blocked with the Block Ace (Dainihon Pharm., Japan) solution for $30 \mathrm{~min}$. Biotinylated lectins (10 $\left.\mu \mathrm{g} \mathrm{ml}^{-1}\right)$ in PBS containing $0.1 \%$ Tween 20 (PBS-Tween) were added to the strips and incubated for $30 \mathrm{~min}$. Peroxidase-labelled avidin (5 $\mu \mathrm{g} \mathrm{ml}^{-1}$, Sigma), in PBS-Tween was then added to the strips and incubated for $30 \mathrm{~min}$. Color was developed with 3,3'-diaminobenzidine tetrahydrochloride (DAB) substrate kit (Funakoshi, Japan) according to the manufacturer's instructions. The reaction was stopped by washing the strips in distilled water, followed by drying in warm air. The $5 \mathrm{~min}$ washing was repeated 3 times between each step, and all steps were performed with shaking.

Phagocytic activity assay. Purified Glugea plecoglossi spores were treated with 8 lectins. Spore suspensions were resuspended in each lectin $\left(25 \mu \mathrm{g} \mathrm{ml}^{-1}\right.$, in PBS) and incubated for $2 \mathrm{~h}$ with stiring at RT. Then suspensions were washed with sterilized PBS 3 times. The control was suspended in sterilized PBS without lectins.

Monolayers of macrophages from the head kidney of ayu were prepared as described previously (Kim et al. 1998). Head kidney of ayu was removed aseptically and pushed through a stainless steel mesh with serumfree Eagle's minimum essential medium (MEM, Sigma) with $1 \%$ antibiotic/antimycotic solution $\left(10000 \mathrm{U} \mathrm{m}^{-1}\right.$ penicillin $\mathrm{G}, 10 \mathrm{mg} \mathrm{ml}^{-1}$ streptomycin, $25 \mu \mathrm{g} \mathrm{ml} \mathrm{m}^{-1}$ amphotericin B, Gibco, USA). The resultant suspensions were layered on the $34 / 51 \%$ Percoll (Sigma) gradient and centrifuged at $400 \times g$ for $25 \mathrm{~min}$, thereby collecting the partially enriched macrophage suspensions lying above the $34 / 51 \%$ interface (Braun-Nesje et al. 1981). The cell suspension was adjusted to $2 \times$ $10^{7}$ cells ml ${ }^{-1}$ with MEM. Aliquots $(300 \mu \mathrm{l})$ were added in 8-well tissue culture chamber slides (Nunc, Denmark) and incubated under $5 \% \mathrm{CO}_{2} / 95 \%$ air at $20^{\circ} \mathrm{C}$. After $2 \mathrm{~h}$, non-adherent cells were washed off with MEM and the monolayers were maintained with MEM containing $5 \%$ fetal calf serum (Boehringer Mannheim $\mathrm{GmbH}$, Germany) and $1 \%$ antibiotic/antimycotic solution.

The proportion of macrophages within the Percollpurified cell suspensions was determined by nonspecific esterase activity, as described by Wang et al. (1995). Adherent cells on the slides were fixed with citrate-acetone-methanol fixative $(36 \% 0.05 \mathrm{M}$ citrate solution, $54 \%$ acetone and $10 \%$ methanol) for $10 \mathrm{~s}$ at RT and washed thoroughly in deionized water. The slides were stained with $\alpha$-naphthyl acetate esterase solution (Sigma) at $37^{\circ} \mathrm{C}$ for $30 \mathrm{~min}$. Then the slides were rinsed for 2 to $3 \mathrm{~min}$ in running tap water and counterstained with Mayer's hematoxylin solution for 
$10 \mathrm{~min}$. Cells stained in greenish brown color were identified as macrophages. Cells were counted 3 times and the proportion of macrophages was expressed as the percentage of esterase-positive cells within 100 cells.

Non-adherent cells were washed off with warm Hank's balanced salt solution (HBSS, Sigma), then the lectintreated Glugea plecoglossi spore suspensions in MEM were added to the macrophage monolayer. After incubation for $2 \mathrm{~h}$ at $20^{\circ} \mathrm{C}$, the non-adherent or non-internalized parasites were washed off and macrophage monolayers on the slides were fixed with methanol immediately. Fixed cells were stained with Giemsa solution (Merck, USA) to count the phagocytized spores. Percentage phagocytosis (PP) was determined by examination

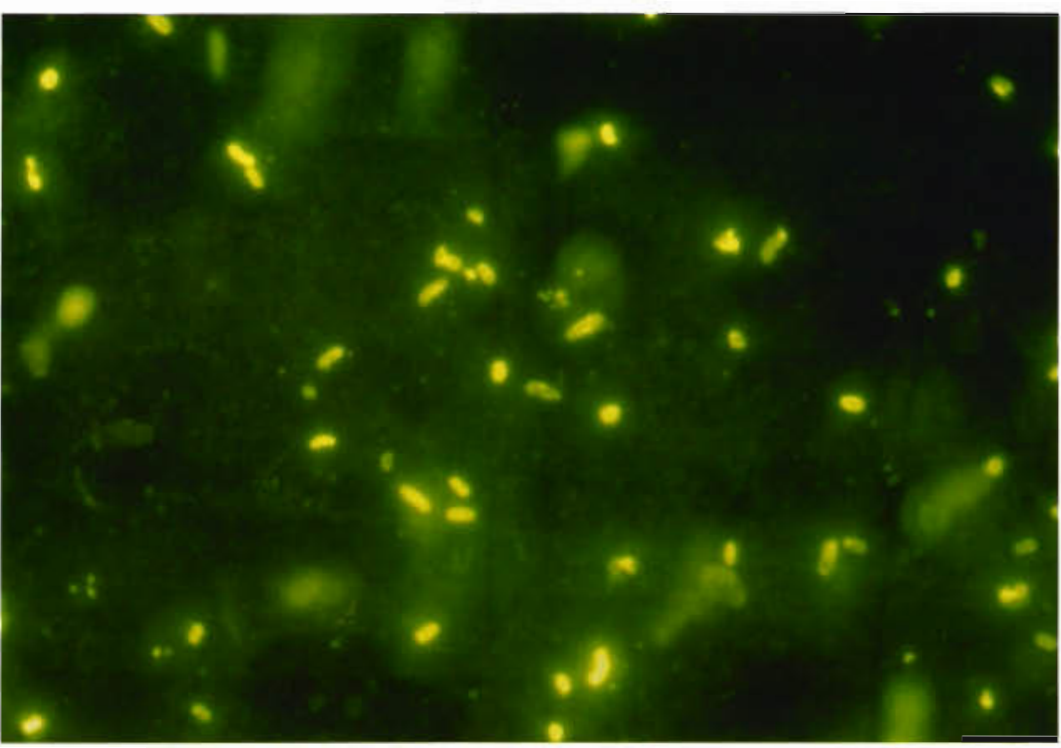

Fig. 1. Glugea plecoglossi spores reacted with biothinylated ConA and FITClabelled avidin of 100 cells, as the percentage of cells which phagocytized $G$. plecoglossi spores. Phagocytic index (PI) was determined as the mean number of spores per 1 phagocytic macrophage. Spores not treated with lectins were used as controls and all assays were conducted in triplicate.

Statistical analysis. Data were analyzed by Student's t-tests.

\section{RESULTS}

\section{Lectin-binding pattern of Glugea plecoglossi spores}

The results are summarized in Table 2. Of 8 lectins used in this experiment, the typical bright apple green color was seen only when ConA and WGA were applied (Fig. 1). Other lectins showed pale or no fluorescence.

\section{Lectin blot}

Many bands were observed when ConA and WGA were applied to the strips after transfer (Fig. 2). ConA recognized several protein bands in the range between 45 and $57 \mathrm{kDa}$, and the most prominent band had $55 \mathrm{kDa}$. Similarly, several bands were visualized when WGA was applied and prominent WGA binding proteins had $55 \mathrm{kDa}$. Other minor bands, which ranged between 45 and $120 \mathrm{kDa}$, were not as clear as those of ConA. The other 6 lectins did not show prominent protein bands and most bands were negligible.

\section{Phagocytic activity assay}

The proportion of macrophages, which were positive for esterase, was $71.3 \%$ of the Percoll-purified adherent cells. PP was significantly reduced when the spores were treated with ConA ( $p<0.01$; Fig. 3). Although WGA recognized several protein bands in the lectin blot experiment, its effect on the PP was not statistically significant. Other lectins had no significant effect.

When the lectin-treated spores were added to the macrophage monolayers, PI was reduced for all 8 lectins. The values of PI in the tested groups ranged between 1.54 and 2.01, and all decreased significantly when compared to controls (2.69 \pm 0.09 ) (Fig. 4).

\section{DISCUSSION}

In this study, we show that Glugea plecoglossi spores have lectin-reactive components. Furthermore, phago-

Table 2. Lectin binding pattern of Glugea plecoglossi spores

\begin{tabular}{|lc|}
\hline Lectin & Reactivity to the spores of G. plecoglossi \\
\hline ConA & + \\
DBA & $+/-$ \\
LCA & - \\
PNA & - \\
SBA & - \\
UEA-I & $+1-$ \\
PHA-E4 & $+/-$ \\
WGA & + \\
\hline
\end{tabular}




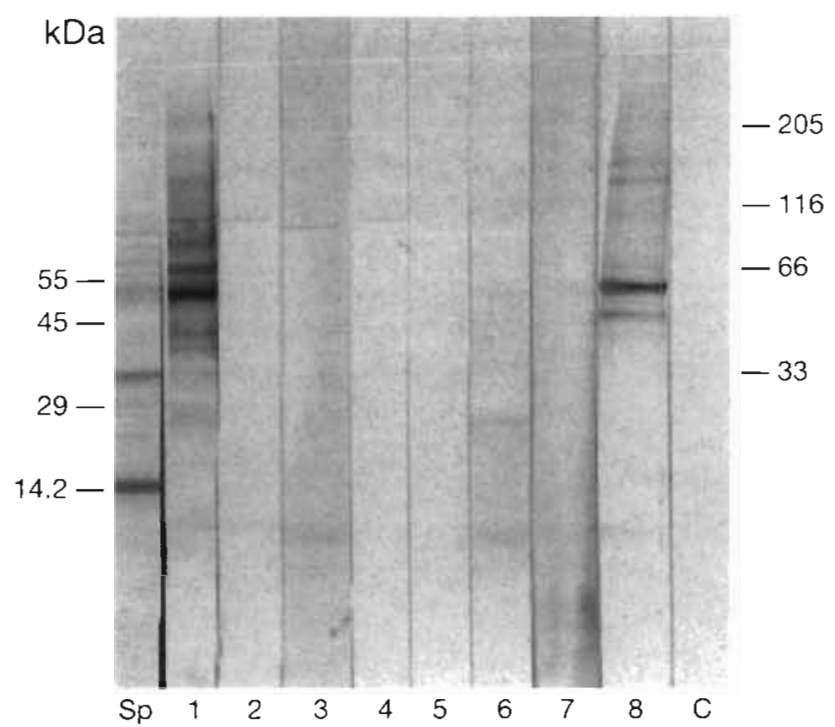

Fig. 2. Detection of glycoproteins of Glugea plecogloss spores with biotinylated lectins and peroxidase-labelled avidins Sp: spore proteins; lane 1. ConA; lane 2: DBA; land 3: LCA lane 4: $\mathrm{PNA}_{\text {; }}$ lane 5: $\mathrm{SBA}_{\text {; lane }}$ 6: UEA-1; lane 7: PH.A; lane 8: WGA; $C$ : control (without lectins). Numbers on left and right indicate molecular weight of standards $\mathrm{kDa}$

cytosis of $G$. plecoglossi spores by the head kidney macrophages of ayu was influenced by lectin treatment: ConA and WGA reacted to the spores, and the phagocytosis of the spores was significantly inhibited after ConA treatment.

Lectins have been used for many purposes in parasitology (Jacobson \& Doyle 1996). In particular, their specific binding to parasites has been used to define

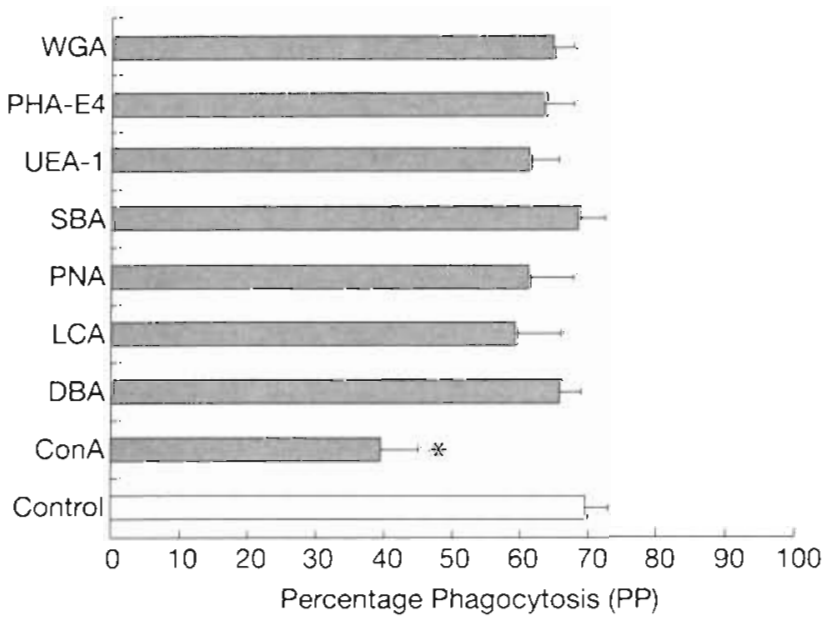

Fig. 3. Effect of lectin treatment on the phagocytosis of Glugea plecoglossi spores by head kidney macrophages of ayu. Percentage phygocytosis (PP): percentage of cells which phagocytized the spores. Results are the means of triplicate counts plus standard errors. *Significantly different from control, $\mathrm{p}<0.01$

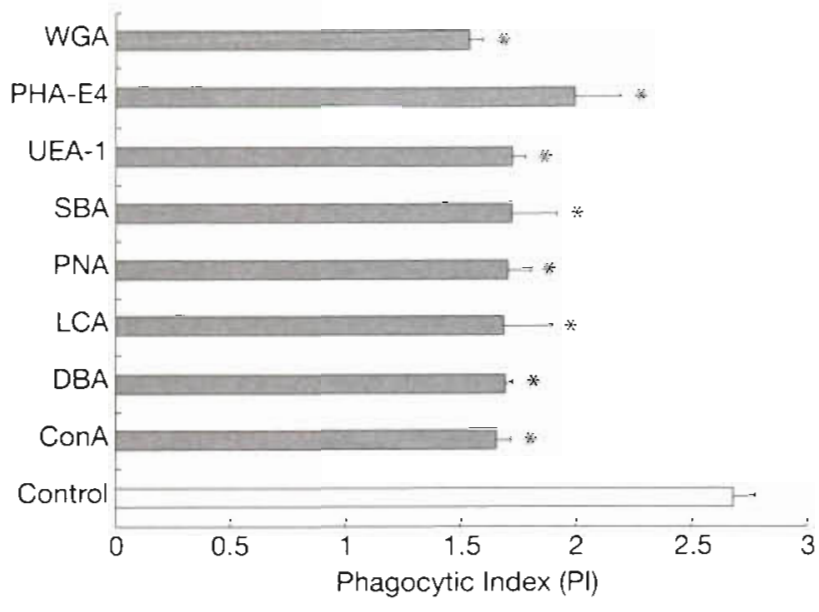

Fig. 4. Effect of lectin treatment on the phagocytosis of Glugea plecoglossi spores by head kidney macrophages of ayu. Phagocytic index (PI): mean number of G. plecoglossi spores cell $^{-1}$ Results are the means of triplicate counts plus standard errors, *Significantly different from control, $p<0.01$

developmental stages of the parasites and to discriminate between pathogens and non-pathogens. Moreover, glycoconjugates, which commonly exist on parasite surfaces or in the internal structures of the parasites, can bind actively to lectins. These binding activities are related to the infection process in some protozoan parasites (Alexander \& Russell 1985, Zingales \& Colli 1985). Delbac et al. (1995) reported the existence of glycoproteins in the microsporidian Encephalitozoon cuniculi. They visualized lectinreactive glycoproteins of the parasite on blots after treatment with 4 kinds of lectins (ConA, PNA, RCA, WGA), and all of them bound to a $52 \mathrm{kDa}$ band. In our experiments, only ConA and WGA showed reactivity, Other lectins, including PNA and $R C A$, showed no or negligible reactivity. A major band visualized in our study was the $55 \mathrm{kDa}$ band. These differences may be due to generic differences of the parasites.

Leiro et al. $(1996,1997)$ suggested that the phagocytosis of microsporidian spores by teleost macrophages could occur by lectin-sugar interactions. They showed that the rate of phagocytosis decreased after treating spores with enzymes or sodium $m$-periodate, and suggested these phenomena were due to changes in surface spore structures. In our experiments, PP significantly decreased after ConA treatment. This could be explained by changes in surface structure of the spores, caused by blocking with ConA. WGA had no significant effect on $\mathrm{PP}$, although a few bands were detected in the lectin blot. This difference may be due to the slight structural differences in proteins which have similar molecular weight. 
PI decreased with all the lectins used in this study. We have no information about why all the lectins had this effect, yet only ConA affected PP. One of the possible reasons may be because the lectins bind nonspecifically, and this cannot be detected by the methods used in this study.

Although PP decreased by ConA treatment, it was not possible to suppress phagocytosis completely. This is probably because the percentage of macrophages in purified cell suspensions was not $100 \%$. Although the purification method using Percoll gradient is most commonly used for isolating teleost macrophages, it is still impossible to get $100 \%$ pure macrophage cell suspensions. Hence, other phagocytic cells in the Percoll-purified adherent cell monolayers might phagocytize the spores regardless of the lectin treatment. Otherwise, other lectins as well as ConA may also have a minor, but important role in spore phagocytosis.

Inhibition of penetration or adherence of some pathogenic protozoan parasites by treatment with glycoproteins or carbohydrates has been reported (Schulman et al. 1984, Yang et al. 1997). This inhibition may lead to the prevention of infection because adherence and penetration are the prerequisites for infection by intracellular parasites. The results reported here indicate that Glugea plecoglossi infection can be controlled by manipulating spore-macrophage interactions. More detailed studies are needed to clarify the exact roles of spore-macrophage interactions in vivo.

Acknowledgements. We would like to thank all staff of Yamanashi Prefectural Fisheries Technology Center and Fisheries Laboratory of the University of Tokyo for providing and rearing the experimental fish, and $\mathrm{Mr} \mathrm{T}$. Saito of Kumamoto Prefectural Fisheries Research Center for providing Glugea plecoglossi-infected ayu. Our special thanks go to Dr Craig $J$. Hayward from the same laboratory for kindly correcting the English of the manuscript.

\section{LITERATURE CITED}

Alexander J، Russel DJ (1985) Parasite antigens, their roles in protection, diagnosis and escape: the leishmaniases. Curr Top Microbiol Immunol 120:43-67

Beuth J, Ko HL, Pulverer G, Uhlenbruck G, Pichlmaier $\mathrm{H}$ (1995) Glycopinion minireview-importance of lectins for the prevention of bacterial infections and cancer metastases. Glycoconjugate J 12:1-6

Braun-Nesje R, Bertheussen K, Kaplan G, Seljelid R (1981) Salmonid macrophages: separation, in vitro culture and characterization. J Fish Dis 4:141-151

Delbac F, Duffieux F, David D, Metenier G, Prensier G, Vivares C (1995) Immunolocalization and partial characterization of proteins from the microsporidium Encephalitozoon cuniculi, an AIDS opportunistic parasite. Eur J Protistol 31:417
Ezekowitz RAB, Williams DJ, Koziel H, Armstrong MYK, Warner A, Richards FF, Rose RM (1991) Uptake of Pneumocystis carinii mediated by the macrophage mannose receptor. Nature 351: 155-158

Hedrick RP, Marin M, Castagnaro M, Monge D, de Kinkelin P (1992) Rapid lectin-based staining procedure for the detection of the myxosporean causing proliferative kidney disease in salmonid fish. Dis Aquat Org 13:129-132

Hernandez AG, Rodriguez N, Stojanovic D, Candelle D (1986) The localization of a lectin-like component on the Leish mania cell surface. Mol Biol Rep 11:149-153

Jacobson RL, Doyle RJ (1996) Lectin-parasite interactions. Parasitol Today 12:55-60

Kim JH, Ogawa K, Wakabayashi $\mathrm{H}$ (1998) Respiratory burst assay of head kidney macrophages of ayu, Plecoglossus altivelis, stimulated with Glugea plecoglossi (Protozoa: Microspora) spores. J Parasitol 84:552-556

Laemmli UK (1970) Cleavage of structural proteins during the assembly of the head of bacteriophage T4. Nature 227 $680-685$

Leiro J, Ortega M, Estévez J, Ubeira FM, Sanmartín ML (1996) The role of opsonization by antibody and complement in in vitro phagocytosis of microsporidian parasites by turbot spleen cells. Vet Immunol Immunopathol 51. $201-210$

Leiro J, Ortega $M$, Siso MrG, Sanmartín ML, Ubeira FM (1997) Effects of chitinolytic and proteolytic enzymes on in vitro phagocytosis of microsporidians by spleen macrophages of turbot, Scophthalmus maximus L. Vet Immunol Immunopathol 59:171-180

Schmidt EC. Shadduck JA (1984) Mechanisms of resistance to the intracellular protozoan Encephalitozoon cuniculi in mice. J Immunol 133:2712-2719

Schulman S, Lee YC, Vanderberg JP (1984) Effects of neoglycoproteins on penetration of Plasmodium falciparum merozoites into erythrocytes in vitro. J Parasitol 70:213-216

Scott MT, Snary D (1979) Protective immunisation of mice using cell surface glycoprotein from Trypanosoma bruces. Nature 282:73-74

Sharon N (1984) Surface carbohydrates and surface lectins are recognition determinants in phagocytosis. Immunol Today 5:143-147

Sharon N, Lis H (1989) Lectins as cell recognition molecules. Science 246:227-234

Thornton DJ, Carlstedt I, Sheehan JK (1994) Identification of glycoproteins on nitrocellulose membranes and gels. In: Walker JM (ed) Methods in molecular biology, Vol 32. Basic protein and peptide protocols. Humana Press, Totowa, NJ, p 119-128

Vavra J, Yachnis AT, Shadduck JA, Orenstein JM (1998) Microsporidia of the genus Trachipleistophora - causative agents of human microsporidiosis: description of Trachipleistophora anthropophthera n. $\mathrm{sp}$. (Protozod: Micrasporidia). J Eukaryot Microbiol 45:273-283

Wang R, Neumann NF, Shen Q, Belosevic M (1995) Establishment and characterization of a macrophage cell line from the goldfish. Fish Shellfish Immunol 5:329-346

Weidner E, Sibley LD (1985) Phagocytized intracellular microsporidian blocks phagosome acidification and phagosomelysosome fusion. J Protozool 32:311-317

Yang Z, Cao Z, Panjwani N (1997) Pathogenesis of Acanthamoeba keratitis: carbohydrate-mediated host-parasite interactions. Infect Immun 65:439-445

Zingales B, Colli W (1985) Trypanosoma cruzi: interaction with host cells. Curr Top Microbiol Immunol 117:129-152

Submitted: August 11, 1999; Accepted: October 18, 1999

Proots received from author(s): November 30, 1999 